\title{
Sub chronic toxicity effect of combination of herbal juice on the function and histopathology feature of male Wistar rat liver
}

\section{Efek toksisitas subkronik jus herbal kombinasi (bawang putih, bunga rosella, jahe merah, jeruk nipis, cuka apel dan madu) terhadap fungsi dan gambaran histopatologi hati tikus jantan galur Wistar}

\author{
Ade Arinia Rasyad ${ }^{1}$, Aisah ${ }^{1}$, Lidia $^{1}$, Sari Meisyayati ${ }^{1}$ \\ ${ }^{1}$ Program Studi S1 Farmasi, STIFI Bhakti Pertiwi, Palembang, Indonesia \\ *Corresponding author: adearinia74@gmail.com
}

\begin{abstract}
Background: Previous study found the activity of the combination herbal juice of garlic, rosella flower, red ginger, lime, apple cider vinegar, and honey lowering the blood sugar and total cholesterol levels. Along with its effectiveness, the safety profile must be addressed prior to the distribution in community.

Objective: This study aim was to determine the sub-chronic hepatotoxic effect of the combination of herbal juice

Method: This research employed 24 rats divided into four groups, namely control group (aquadest) and three treatment group administered by the combination of herbal juice at dose of 28,14 , and $7 \mathrm{mg} / \mathrm{kg}$ BW/day for 28 days. The parameters to be determined were the increased of SGOT and SGPT level and histopathological features of liver cells. It then statistically analyzed using one-way ANOVA.

Results: The administration of combination of herbal juice for 28 days at a dose of 28,14 , and $7 \mathrm{mg} / \mathrm{kg} \mathrm{BW} /$ day did not increase SGOT level but caused significant decrease in SGPT levels as follow 20.34\%, 19.39\%, and $15.30 \%$ respectively. Moreover, there was no damage of liver cell based on the histopathological observation at a dose of $28 \mathrm{mg} / \mathrm{kg} \mathrm{BW/day.}$

Conclusion: Sub-chronic administration of combined herbal juice did not elicit hepatotoxicity in male Wistar rats

Keywords: Combination herbal juice, sub-chronic toxicity, histopathology, SGOT, SGPT

\section{Intisari}

Latar belakang: Penelitian sebelumnya membuktikan adanya aktivitas jus herbal kombinasi bawang putih, bunga rosella, jahe merah, jeruk nipis cuka apel dan madu dapat menurunkan gula darah dan kadar kolesterol total. Dalam penggunaan obat tradisional, selain efektifitasnya, keamanan menjadi poin penting untuk dibuktikan sebelum dipasarkan dimasyarakat.

Tujuan: Penelitian ini bertujuan untuk mengetahui efek hepatotoksik subkronik dari jus herbal kombinasi.

Metode: Sebanyak 24 ekor tikus dalam penelitian ini dibagi dalam 4 kelompok, yaitu kelompok kontrol (akuades) dan 3 kelompok yang diberi jus herbal kombinasi dengan dosis 28, 14 dan $7 \mathrm{mg} / \mathrm{kgBB} / \mathrm{hari}$ selama 28 hari. Parameter yang diukur adalah peningkatan kadar SGOT dan SGPT serta gambaran histopatologi sel hati. Data dianalisa secara statistik dengan ANOVA satu arah.

Hasil: Pemberian jus herbal kombinasi selama 28 hari dengan dosis 28, 14 dan $7 \mathrm{mg} / \mathrm{kgBB} / \mathrm{hari}$ tidak menyebabkan peningkatan aktifitas SGOT tetapi menyebabkan penurunan kadar SGPT secara signifikan yaitu secara berurutan sebesar 20,34 \%, 19,39\% dan 15,30\%. Dari gambaran histopatologi sel hati, pada dosis 28 $\mathrm{mg} / \mathrm{kggBB} /$ hari tidak ditemukan adanya kerusakan sel hati.

Kesimpulan: Pemberian subkronik jus herbal kombinasi tidak menyebabkan hepatotoksik pada tikus jantan galur Wistar

Kata kunci : Jus herbal kombinasi, toksisitas subkronik, histopatologi, SGOT, SGPT
\end{abstract}




\section{Pendahuluan}

Kekayaan ragam hayati Indonesia, salah satunya tanaman obat, harus dimanfaatkan dalam peningkatan kesehatan maupun ekonomi masyarakat. Sehingga kedepan dapat menjadi salah satu sumber devisa negara (Bahar, 2011). Tanaman obat merupakan salah satu alternatif dalam penyembuhan dan telah digunakan secara turun temurun. Tanaman obat dipercaya memiliki berbagai khasiat secara empiris, namun demikian untuk dapat dijadikan suatu sediaan obat harus dilakukan serangkaian pengujian (Reskianingsih, 2014).

Gerakan back to nature membuat penggunaan tanaman sebagai obat tradisional menjadi meningkat seiring rekomendasi organisasi kesehatan dunia World Health Organization (WHO) bahwa obat tradisional dapat digunakan untuk memelihara kesehatan masyarakat, mencegah dan mengobati penyakit (Madihah et al., 2017). Masyarakat pada umumnya meyakini bahwa obat tradisional aman dan tidak memiliki efek samping. Meskipun sebenarnya, obat tradisional berbahan tanaman herbal mengandung berbagai zat kimia yang kompleks dan berpotensi terjadinya interaksi yang membahayakan serta menimbulkan gejala toksik. Untuk memberikan efek, tanaman obat harus dikonsumsi secara kontinyu dalam jangka waktu yang cukup lama. Hal ini menyebabkan kemungkinan adanya toksisitas subkronik maupun kronis. Suatu produk herbal harus melalui evaluasi keamanan berupa pengujian ketoksikan, untuk dapat didistribusikan secara luas di masyarakat (BPOM RI, 2010).

Dalam uji ketoksikan, selain mengamati gejala toksik yang muncul, observasi fungsi organ juga dilakukan untuk melihat keparahan efek toksik yang ditimbulkan dari suatu pemejanan. Beberapa organ yang sering digunakan dalam pengamatan efek toksik diantaranya adalah hati, ginjal, jantung dan otak. Hati adalah organ terbesar yang berfungsi memetabolisme berbagai zat yang masuk ke dalam tubuh, termasuk di dalam nya adalah obat. Hati dapat mendetoksifikasi zat beracun yang masuk, namun beberapa zat yang awalnya tidak berbahaya saat dimetabolisme hati justru menjadi bersifat toksik. Organ hati tersusun dari hepatosit (sel-sel hati) yang mengandung enzim sebagai katalisator ataupun proses metabolisme (Lu, 1995). Kerusakan hepar dimulai dengan perlemakan hati yang reversible hingga nekrosis yang irreversible. Saat terjadi nekrosis hepatosit, beberapa enzim akan dilepaskan ke ekstrasel. Oleh karenanya fungsi hati dapat diamati dengan deteksi enzim hati yang ada di serum (Baron, 1990; Sari, 2016).

Berbagai penelitian telah dilakukan untuk mengeksplorasi obat alternatif dalam penanganan gangguan hepar. Kombinasi bawang putih, bunga rosella, jahe merah, jeruk nipis, cuka apel dan madu yang memiliki kandungan senyawa aktif kimia berupa flavonoid, terbukti mampu menurunkan kadar kolesterol sebesar 22,6\% pada dosis 5,4 ml/kgBB tikus (Meisyayati et al., 2021). Lebih lanjut, 
berdasarkan hasil penelitian Afriandi (2017), jus herbal kombinasi tersebut pada dosis 7,8 ml/kgbb mencit juga dapat menurunkan gula darah sebesar 50,68\%. Terkait profil kemanannya, penelitian Fitriani (2018) menjelaskan bahwa jus herbal herbal kombinasi bawang putih, bunga rosella, jahe merah, jeruk nipis, cuka apel, dan madu mampunyai nilai $L_{50}$ sebesar 120,16 g/kgBB pada pengujian ketoksikan akut. Hasil tersebut menunjukkan bahwa kombinasi jus herbal praktis tidak toksik. Meskipun demikian, penggunaan obat herbal yang membutuhkan durasi cukup panjang menjadikan evaluasi kemanan jangka panjang menjadi penting untuk dilakukan. Oleh karenanya, penelitian ini ditujukan untuk melihat profil keamanan kombinasi jus herbal secara subkronik menggunakan hewan uji tikus jantan galur Wistar terhadap fungsi dan gambaran histopatologis hati.

\section{Metode}

\subsection{Persiapan hewan uji}

Sebanyak 24 ekor tikus jantan galur Wistar berumur 2-3 bulan, 180-200 gram dan dalam keadaan sehat, diaklimatisasi selama 7 hari dengan pemberian makan dan minum ad libitum. Selama aklimatisasi, dipastikan bobot tikus tidak berubah > 10\%. Pada akhir penelitian, seluruh hewan uji diterminasi dengan dislokasi leher.

\subsection{Pembuatan jus herbal}

Tabel. 1. Formula jus herbal kombinasi

\begin{tabular}{clc}
\hline No & Bahan & Jumlah dalam $15 \mathrm{ml}$ \\
\hline 1 & Sari bawang putih & $1 \mathrm{ml}$ \\
2 & Sari jahe merah & $3 \mathrm{ml}$ \\
3 & Sari jeruk nipis & $1 \mathrm{ml}$ \\
4 & Cuka apel & $1 \mathrm{ml}$ \\
5 & Madu alami & $7 \mathrm{ml}$ \\
6 & Sari bunga rosella & $2 \mathrm{ml}$ \\
\hline
\end{tabular}

Pembuatan jus herbal diawali dengan cara pembersihan masing-masing bahan yaitu bawang putih, jahe merah, dan jeruk nipis dari kulitnya. Untuk bunga rosela, dibersihkan bagian bunganya untuk diambil bagian kelopaknya. Sebanyak masing-masing 1kg bahan, dilakukan pencucian dengan air mengalir dan diekstraksi mengunakan juice extractor. Setelah homogen, sari bawang putih, bunga rosella, jahe merah, dan jeruk nipis dipanaskan selama \pm 5 menit dengan suhu $40^{\circ}-50^{\circ} \mathrm{C}$. Cuka apel dan madu ditambahkan setelah dingin dan diaduk hingga homogen.

\subsection{Uji ketoksikan subkronik}

Dalam pengujian ketoksikan, tikus dibagi menjadi 4 kelompok yaitu 3 kelompok perlakuan (variasi dosis 7,14, $28 \mathrm{mg} / \mathrm{kg} \mathrm{BB}$ ) dan 1 kelompok kontrol normal (diberi akuades). Pada hari ke-0, sebelum dimulai perlakuan, tikus ditimbang berat badan nya dan dipuasakan selama 8 jam. Pada hari 
ke-1, perlakuan dimulai dengan pemberian perlakuan sesuai kelompoknya secara per oral. Perlakuan diberikan sehari sebanyak 3x setiap 3 jam selama 18 hari. Hewan uji yang mati selama perlakuan dan sebelum melewati periode rigor mortis (kaku) segera dinekropsi untuk diisolasi organ hati dan selanjutnya dibuat preparat histopatologis (BPOM RI, 2010).

\subsection{Pemeriksaan SGOT dan SGPT}

Pada hari ke 29, darah tikus diambil melalui pembuluh vena leher, dimasukkan kedalam tabung sentrifus dan disentrifugasi pada kecepatan 5000 rpm (10 menit) untuk diambil serumnya. Penetapan kadar SGOT dan SGPT dilakukan dengan alat Biosistem A 15 pada panjang gelombang 340 nm. Pemeriksaan dilakukan di Balai Besar Labolatorium Kesehatan Daerah Sumatera Selatan.

\subsection{Pembuatan preparat histopatologis hati tikus}

Setelah penetapan kadar SGOT dan SGPT, tikus diterminasi dan diisolasi organ hatinya. Selanjutnya, organ yang diisolasi dibersihkan dengan $\mathrm{NaCl}$ 0,9 \%, direndam dalam larutan formalin 10\% selama 24 jam. Proses selanjutnya berupa pemotongan dan pewarnaan HE agar sel-sel hati dapat diamati dengan mikroskop. Pengamatan yang dilakukan berupa struktur dari hepatosit yang normal maupun yang telah mengalami perubahan, yaitu nekrosis. Tahapan ini dilakukan di laboratorium khusus patologi anatomi Dyanitalis Palembang.

\section{Hasil dan pembahasan}

\subsection{Hasil rendemen jus herbal kombinasi}

Pada proses ekstraksi, dilakukan pemanasan $40^{\circ}-50^{\circ} \mathrm{C}$ yang bertujuan untuk membunuh bakteri yang terikut dan menghindari kontaminasi selama proses penyarian. Penambahan cuka apel dan madu setelah sari jus dingin dikarenakan cuka apel dapat menimbulkan bau yang menyengat saat dipanaskan dan enzim pada madu akan menjadi rusak karena terdenaturasi (Noviyanti \& Ardiningsih, 2012). Pada akhir tahapan ekstraksi, dihasilkan rendemen ekstrak berturut-turut sebesar 23,4; 48,0; 52,0 dan $50,0 \%$.

3.2. Kadar SGOT dan SGPT setelah pemberian jus herbal kombinasi berikut.

Hasil penetapan kadar SGOT dan SGPT pada tikus jantan galur Wistar tertuang pada tabel 2

Tabel 2. Kadar SGOT dan SGPT setelah 28 hari pemberian jus herbal kombinasi

\begin{tabular}{llcc}
\hline No & Kelompok & Nilai rerata SGOT \pm SD (UI/L) & Nilai rerata SGPT \pm SD (UI/L) \\
\hline 1 & Kontrol & $299,20 \pm 15,28$ & $114,96 \pm 15,28$ \\
2 & $28 \mathrm{ml} / \mathrm{kgBB}$ & $300,59 \pm 95,26$ & $91,57 \pm 20,68$ \\
3 & $14 \mathrm{ml} / \mathrm{kgBB}$ & $299,10 \pm 57,26$ & $92,66 \pm 9,64$ \\
4 & $7 \mathrm{ml} / \mathrm{kgBB}$ & $335,29 \pm 62,59$ & $97,36 \pm 8,95$ \\
\hline
\end{tabular}


Dari tabel 2 dapat dilihat bahwa kadar SGOT antar kelompok perlakuan hampir sama dan tidak berbeda bermakna $(p<0,05)$. Namun demikian, nilai SGOT seluruhnya pada rentang normal 70-400 UI/L (God, 1992) dan dapat disimpulkan bahwa pemberian jus herbal kombinasi tidak memberikan efek pada nilai SGOT. Sedangkan pada nilai SGPT terlihat bahwa ada perbedaan bermakna antara kelompok perlakuan jus herbal dengan kontrol $(\mathrm{p}<0,05)$, meskipun antar dosis pemberian nya tidak berbeda signifikan dan masih masuk rentang normal 25-200 UI/L (God, 1992). Terjadinya penurunan ini diduga karena adanya kandungan flavonoid pada jus herbal kombinasi yang bersifat antioksidan kuat. Senyawa organosulfur dan fenolik sebagai antioksidan yang terdapat dalam kandungan bawang putih memegang peranan penting dalam mencegah kerusakan sel dan organ organ radikal bebas (Prasonto et al., 2017) yang sejalan dengan fungsi antioksidan dari masingmasing bahan yang lain.

\subsection{Gambaran histopatologi}

Hasil pembacaan preparat histopatologik sel hepar dibawah mikroskop terlihat pada Gambar 2 dibawah.

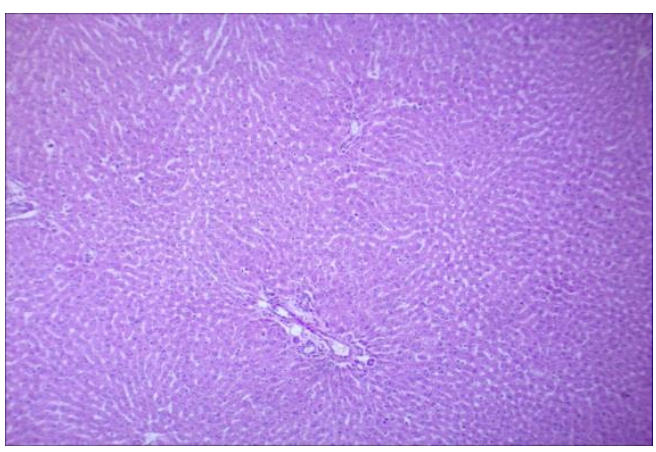

(a)

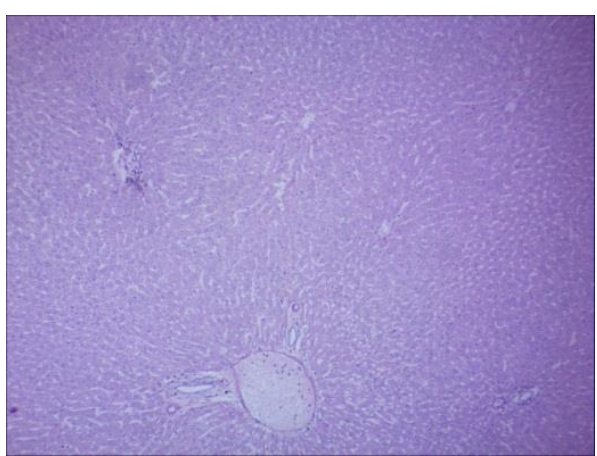

(b)

Gambar 2. Gambaran histopatologi Setelah pemberian jus herbal dosis $28 \mathrm{mg} / \mathrm{kgBB} / \mathrm{hari}$ selama 28 hari

Keterangan : (a) = Setelah pemberian akuades terlihat normal

(b) = Setelah pemberian jus herbal kombinasi pada dosis $28 \mathrm{mg} / \mathrm{kgBB} / \mathrm{hari}$ terlihat tidak adanya nekrosis

Pengamatan dilakukan pada hepar tikus yang mendapat dosis tertinggi jus herbal kombinasi, yaitu $28 \mathrm{mg} / \mathrm{kgBB}$ dan tikus normal. Dengan perbesaran 400x setelah pewarnaan HE, tampak bahwa hepar perlakuan maupun normal tidak ada perubahan maupun kerusakan sel. Sel-sel hepar (hepatosit) tampak normal, tidak ada degenerasi hidropik, melemak, maupun nekrosis. Kandungan flavonoid pada jus herbal kombinasi dapat mengaktifkan sel kuffer untuk meregeneresi sel hati, dan terdapat kandungan melatonin dalam jahe merah yang dapat berfungsi sebagai penangkal radikal bebas penyebab kerusakan hati (Pertiwi \& Widyaningsih, 2015). Hasil ini sejalan dengan penelitian 
menggunakan bahan herbal yang terbukti memberikan efek hepatoprotektor. Penelitian Astuti dkk (2016) membuktikan efek hepatoprotektor infusa akar tawas terhadap mencit dengan dosis $30 \%$ memberikan nilai SGPT dan SGOT yang lebih rendah dibandingkan kontrol. Penelitian lain oleh Panjaitan dkk (2011) menunjukkan adanya aktifitas hepatoprotektor ekstrak metanol akar pasak bumi dapat menekan kadar alanin transaminase (ALT/ SGOT) dan aspartat transaminase (AST/ SGPT) dalam serum dibandingkan kontrol yang diperkuat dengan gambaran histopatologi sel hati yang mengalami perbaikan. Selain itu, berdasarkan penelitian Iralawati dkk (2012), menyatakan bahwa jus belimbing manis memiliki efek hepatoprotektor terhadap penurunan kadar SGOT dan SGPT yang telah diinduksi oleh rifampisisn dan isoniazid. Oleh karenanya, jus herbal kombinasi bawang putih, bunga rosella, jahe merah, jeruk nipis, cuka apel dan madu tidak menyebabkan ketoksikan dilihat dari parameter enzim hati maupun gambaran histopatologis sel hati.

\section{Kesimpulan}

Pemberian jus herbal kombinasi bawang putih, bunga rosella, jahe merah, jeruk nipis, cuka apel, dan madu hingga dosis $28 \mathrm{mg} / \mathrm{kgBB}$ tidak menyebabkan ketoksikan sub-kronik tikus jantan galur Wistar berdasarkan parameter nilai SGPT dan SGOT, serta gambaran histopatologis hepar.

\section{Ucapan terimakasih}

Terimakasih banyak penulis haturkan kepada ketua Yayasan Notari dan Ketua STIFI Bhakti Pertiwi atas bantuan dana, tempat dan peralatan sehingga terlaksananya penelitian ini. Terimakasih juga kepada Balai Besar Labolatorium Kesehatan Daerah Sumatera Selatan dan Laboratorium Khusus Patologi Anatomi Dyanitalis Palembang atas fasilitas dan bantuan Analisa Patologi Anatominya sehingga penulis bisa menyimpulkan hasil penelitian ini dengan data-data yang akurat dan bisa dipertanggung jawabkan.

\section{Daftar pustaka}

Afriandi, A. (2017). Uji Efek Antidiabetes Jus Herbal Kombinasi (Bunga rosella, JaheMerah, Jeruk Nipis, Cuka Apel, dan Madu) pada Mencit Putih Jantan yang Diinduksi Aloksan (Skripsi). Sekolah Tinggi Ilmu Farmasi Bhakti Pertiwi, Palembang.

Astuti, K. I., Anwar, K., \& Biworo, A. (2016). Uji Aktivitas Infusa Akar Tawas Ut (Ampelocissus rubiginosa L.) Sebagai Hepatoprotektor Terhadap Mencit Putih Jantan Balb/C yang Diinduksi Karbon Tetraklorida (CCl4). Jurnal Pharmascienve 3(2), 57-63.

Bahar, N. W. (2011). Pengaruh Pemberian Ekstrak dan Fraksi Daun Katuk (Sauropus androgynus (I) Merr) terhadap Gambaran Hematologi pada Tikus Putih Laktasi (Skripsi). Institut Pertanian Bogor, Bogor. Retrieved from http://repository.ipb.ac.id/handle/123456789/52332

Baron, D. N. (1990). Kapita Selekta Patologi Klinik (P. Adrianto \& J. Gunawan, Trans. 4 ed.). Jakarta: Penerbit Buku Kedokteran EGC. 
BPOM_RI. (2010). Acuan Sediaan Herbal. Jakarta Direktorat Obat Asli Indonesia

Fitriani, M. (2018). Toksisitas Akut Jus Herbal Kombinasi (Bawang Putih, Bunga Rosella, Cuka Apel, Jahe Merah, Jeruk Nipis, dan Madu) terhadap Mencit Putih Betina. (Skripsi). Sekolah Tinggi Ilmu Farmasi Bhakti Pertiwi, Palembang.

God, S. C. (1992). Animal Models in Toxicology. New York: Marcel Dekker.

Iralawati, A. D., Hermayanti, D., \& Syafitri, F. (2012). Jus belimbing Manis (Averrhoa carambola) sebagai Hepatoprotektor pada Tikus Putih (Rattus novergicus Strain Wistar) yang Diinduksi Antituberkulosis Rifampisin dan Isoniazid. Jurnal Veteriner, 8(2), 127-134.

Lu, F. C. (1995). Asas, Organ Sasaran, dan Penelitian Resiko (E. Nugroho, Trans. 2 ed.): UI Press.

Madihah, M., Ratningsih, N., Malini, D. M., Faiza, A. H., \& Iskandar, J. (2017). Uji Toksisitasa Akut Ekstrak Etanol Kulit Buah Jengkol (Archidendrom pauciflorum) terhadap tikus Witar Betina. Pros Sem Nas Masy Biodiv Indom, 3, 33-38. doi:10.13057/psnmbi/m030107

Meisyayati, S., Risa, M., Juniati, H., Herpi, J., Imanda, Y. L., Isomarina, R., \& Sriwijaya, R. A. (2021). The Effect of Some Herbal Juice Formula on Serum Total Cholesterol Level of High Lipid Diet-PTU Rats. Paper presented at the Proceedings of the First International Conference on Health, Social Sciences and Technology (ICoHSST 2020).

Noviyanti, T., \& Ardiningsih, P. (2012). Pengaruh Temperatur terhadap Aktivitas Enzim Protease dari Daun Sansakng (Pycnarrhena cauliflora Diels). Jurnal Kimia Khatulistiwa, 1(1), 31-33.

Panjaitan, R. G. P., W, M., Handharyani, E., \& Chairul, C. (2011). Aktifitas Hepatoprotektor Ekstrak Metanol Akar Pasak Bumi dan Fraksi-Fraksi Turunanya. Jurnal Veteriner, 12(4), 319-325.

Pertiwi, P. A., \& Widyaningsih, W. l. (2015). The Effect Ethanol Extract of Ulva Lactuca l on SGOT-SGPT Activity in Rat. Traditional Medicine Journa, 20(1), 1-6.

Prasonto, D., Riyanti, E., \& Gartika, M. (2017). Uji Aktivitas Antioksidan Ekstrak Bawang Putih (Allium sativum). ODONTO : Dental Journal, 4, 122. doi:10.30659/odj.4.2.122-128

Reskianingsih, A. (2014). Uji Toksisitas Akut Ekstrak Metanol Buah Phaleria Macrocarpa (Scheff) Boerl terhadap Larva Artemia Salina Leach dengan Metode Brine Shrimp Lethality Test (BSLT). (Skripsi). Universitas Islam Negeri Syarif Hidayatullah, Jakarta

Sari, P. A. M. (2016). Ketoksikan Akut Kombinasi Extrak Bunga Rosella (Hibiscus sabdariffa L) dan Daun Jati Belanda (Guazuma ulmifolia Lamk) dengan Parameter Kadar SGOT dan SGPT Tikus Putih Jantan (Rattus nevergicus). (Skripsi). Fakultas Farmasi Universitas Jember, Jember. 